\title{
Validation of a Scale to Measure the Perception of SARS-CoV-2 Vaccines Acceptance: The VAC-COVID-19 Scale
}

\author{
Christian R. Mejia ${ }^{1^{*}}$, J. Franco Rodriguez-Alarcon ${ }^{2,3}$, Dayana Ticona ${ }^{4}$, Kevin Flores-Lovon ${ }^{4}$, Marco Paredes-Obando ${ }^{5}$, \\ Maryory S. Avalos-Reyes ${ }^{6}$, Laura Ccasa-Valero ${ }^{7}$, Macarena Carbajal ${ }^{8}$, Renzo Felipe Carranza Esteban ${ }^{9}$, Oscar \\ Mamani-Benito ${ }^{10}$, Oriana Rivera-Lozada ${ }^{11}$, Marcos Roberto Tovani-Palone ${ }^{12^{\star *}}$
}

\author{
${ }^{1}$ Translational Medicine Investigation Centre, Universidad Norbert Wiener, Lima, PERU \\ ${ }^{2}$ Asociación Médica de Investigación y Servicios en Salud, Lima, PERU \\ ${ }^{3}$ Facultad de Medicina Humana "Manuel Huaman Guerrero", Universidad Ricardo Palma, Lima, PERU \\ "Universidad Nacional de San Agustín de Arequipa, Arequipa, PERU \\ ${ }^{5}$ Universidad Nacional de la Amazonia Peruana, Loreto, PERU \\ ${ }^{6}$ Universidad Privada Antenor Orrego, La Libertad, PERU \\ Universidad Nacional del Altiplano, Puno, PERU \\ ${ }^{8}$ Universidad Nacional Hermilio Valdizan, Huánuco, PERU \\ ${ }^{9}$ Escuela Profesional de Psicología, Universidad San Ignacio de Loyola, Lima, PERU \\ ${ }^{10}$ Universidad Peruana Unión, Juliaca, PERU \\ ${ }^{11}$ South American Centre for Education and Research in Public Health, Universidad Norbert Wiener, Lima, PERU \\ ${ }^{12}$ Ribeirão Preto Medical School, University of São Paulo, Ribeirão Preto, BRAZIL \\ *Corresponding Author: christian.mejia.md@gmail.com \\ ${ }^{\star \star}$ Corresponding Author: marcos_palone@hotmail.com
}

Citation: Mejia CR, Rodriguez-Alarcon JF, Ticona D, Flores-Lovon K, Paredes-Obando M, Avalos-Reyes MS, Ccasa-Valero L, Carbajal M, Carranza Esteban RF, Mamani-Benito O, Rivera-Lozada O, Tovani-Palone MR. Validation of a Scale to Measure the Perception of SARS-CoV-2 Vaccines Acceptance: The VAC-COVID-19 Scale. Electron J Gen Med. 2021;18(5):em303. https://doi.org/10.29333/ejgm/11012

\section{ARTICLE INFO}

Received: 22 Jan. 2021

Accepted: 20 Mar. 2021

\begin{abstract}
Introduction: Since the announcement of the start of SARS-CoV-2 vaccines development, many myths and vaccine opponents have come to the fore. Therefore, in this scenario, it is imperative to have an instrument to assess the population perception of this subject matter.

Objective: To validate a scale to measure the perception of SARS-CoV-2 vaccines acceptance.

Methods: This is an instrumental and multicentre study, through which a list of possible reasons for whether or not people would be vaccinated was generated. After submitting them to 15 experts, a pilot survey was conducted virtually in a population of almost 3000 participants in the 24 regions of Peru. Descriptive statistics and the exploratory factor analysis (EFA) were conducted using the FACTOR program.

Results: The Kaiser-Meyer-Olkin $(\mathrm{KMO})$ coefficient $(\mathrm{KMO}=0.917)$ and the Bartlett's test of sphericity $(3343.3$; gl = 136; $p$ <.001) were conducted. According to EFA results, two factors were found to explain $58.17 \%$ of the total variance. The fit indices show that the proposed model is adequate $\left(X^{2}=826.321 ; \mathrm{df}=43 ; p=0.001 ; R M R=0.054\right.$; $\mathrm{GFI}=0.952 ; \mathrm{AGFI}=0.927 ; \mathrm{CFI}=0.946 ; \mathrm{TLI}=0.931 ;$ and RMSEA $=0.078)$. Finally, Cronbach's $\alpha$ was found to be very
\end{abstract} satisfactory for the generated scale $(\alpha=0.831 ; 95 \% \mathrm{Cl}=0.82-0.84)$.

Conclusion: A simple and efficient scale was validated to assess positive and negative perceptions of SARS-CoV-2 vaccines (the VAC-COVID-19 scale), with a Cronbach's coefficient of 0.831 .

Keywords: perception, mass vaccination, COVID-19 vaccines, SARS-CoV-2, validation, Peru

\section{INTRODUCTION}

The coronavirus disease 2019 (COVID-19) pandemic has created a global public health emergency due to its rapid spread and significant morbidity and mortality. Several segments of the society have been affected, and so far the number of confirmed cases of the disease worldwide has already exceeded 90 million [1]. As a result, many pharmaceutical companies and countries set out to develop a vaccine to help put an end to the pandemic. Thus, some viable vaccines for mass vaccination against severe acute respiratory syndrome coronavirus 2 (SARS-CoV-2) were developed in a very short time. Although the vaccination is urgent and the health systems of several countries can collapse at any time, its implementation and subsequent immunization are suffering some setbacks [2]. Moreover, there is the precedent that in situations such as this, the health sector often fails to carry out the vaccination process appropriately [3].

Another possible challenge in this context is the vaccine hesitation. Numerous studies conducted of Europe and North America on the population perception of vaccination have reported that greater acceptance of vaccines depends mainly on their safety and efficacy in clinical studies [4]. In addition, length of time of immunity, adverse effects, and the origin of the vaccine has been identified as the main factors associated 
with increasing the likelihood of vaccination among the more vulnerable population [5]. Therefore, determining the number of patients who will reject SARS-CoV-2 vaccines could contribute greatly to clarifying whether collective immunization can be achieved [6].

It should also be noted that knowing the population perceptions of vaccination would be very useful for governments to implement effective campaigns and seek new strategies to achieve positive perception of vaccines $[7,8]$. Nevertheless, studies on vaccine perceptions, especially regarding SARS-CoV-2 vaccines are scarce in the literature. Furthermore, there are no scales or measuring instruments that can help us have a real approach to the population perception of the SARS-CoV-2 vaccination. In this study, we develop and validate a scale to measure the perception of SARS-CoV-2 vaccines acceptance.

\section{METHODS}

\section{Study Type and Design}

An instrumental, cross-sectional, analytical, and multicentric study was conducted in the 24 regions of Peru.

\section{Population and Sample}

First, a sample of 15 professionals with experience in the field of public health, a master's degree in related subjects (epidemiology, public health, or related research), specialization in related subjects (infectious diseases, immunology, internal medicine, or related field), or active in vaccination services (general practitioners, nurses, psychologists, communicators, etc.) were recruited.

Also, a non-random sample of 30 respondents was selected for a pilot phase (prior to the general survey) and another nonrandom sample of 3000 participants from the 24 regions of Peru was used for the application of the general survey. The participants were recruited through social media, email, and phone calls. Our samples were composed of students, workers, and retirees. Although the samples were non-random, every effort was made to ensure that they adequately represented each group of the study.

We included all participants who were over 18 years of age, and who completed the survey correctly (ended the survey) and agreed to participate voluntarily in the study. Participants who lived outside the country in the last six months (considering the date of invitation to participate in the study), or who had COVID-19 complications and not completed the entire survey were excluded ( 16 exclusions). Finally, the study sample consisted of 2984 participants.

\section{Procedures and Instrument}

\section{Item development}

The research team carried out an exhaustive bibliographic search in databases with Spanish and English articles, in addition to consultation to experts in the field. An initial list with 19 items to the survey was obtained, which was divided into two groups of 13 and six items each, including reasons for 'whether or not' the participants would be vaccinated, respectively. Each item had five possible Likert-type responses: strongly disagree, disagree, neither disagree nor agree, agree, and strongly agree.

\section{Scale development}

The next steps included substantive validation (through the evaluation of the 15 experts in the field), form validation (by the 30 participants of the pilot phase), and general survey (with the participation of almost 3000 people). For the substantive validation, the experts gave their assessments through a validation sheet that included the following indicators: representativeness, clarity, and relevance. In each stage, several suggestions were taken into consideration, and necessary changes were made, with the final scale having only 11 items.

Due to the serious socio-epidemiological situation, especially in the northern regions of Peru, we decided that all steps of the research would be done virtually, using the SurveyMonkey, Inc. (San Mateo, California, USA). This platform was chosen due to the possibility of having the option of receiving only one response for each respondent (with filtering for only one response for each item). All of this was developed during the month of December 2020.

\section{Statistical Analysis}

Descriptive analysis and the exploratory factor analysis (EFA) were conducted using the FACTOR program. The mean, standard deviation, asymmetry, and kurtosis of each one the 19 initial items of the scale were analyzed. The value $+/-2$ was adopted to the coefficient of asymmetry and kurtosis [9]. The Bartlett's test of sphericity and the Kaiser-Meyer-Olkin (KMO) coefficient were used for this purpose. EFA was performed using robust ordinary least squares, with an oblique promin rotation. The parallel analysis suggested the existence of two factors [10].

We used the statistical program AMOS (version 21) to estimate the confirmatory factor analysis (CFA) models. The goodness-of-fit index (GFI), the adjusted goodness-of-fit index (AGFI), the Tucker-Lewis index (TLI), and the comparative fit index (CFI) were analyzed based on the structural equation modelling (SEM). Moreover, the the root mean square error of approximation (RMSEA) and the root mean square error (RMR) were calculated following the criteria proposed by $\mathrm{Hu}$ and Bentler [11], who indicated that the GFI, AGFI, TLI, and CFI values should be higher than 0.9 and the RMSEA value lower than 0.08 . Reliability and confidence intervals were determined using the Statistical Package for Social Sciences (SPSS) version 12 (SPSS Inc., Chicago, IL, USA).

\section{Ethics}

The project was developed in accordance with the international ethical and methodological guidelines. It was approved by the committee of Norbert Wiener Private University with registration number 306-2020. The consent for participation was obtained at the beginning of the survey, and only the responses of the professionals who agreed to participate in the study were considered eligible.

\section{RESULTS}

Table 1 shows the calculation of the mean, standard deviation, asymmetry, and kurtosis (descriptive statistics) of the 19 initial items of the VAC-COVID-19 scale. Item 15 has the highest average score $(M=2.92)$, while item 12 the highest dispersion $(S D=1.28)$. The asymmetry and kurtosis values of all items do not exceed the range $+/-2$ [9]. On the other hand, 
Table 1. Preliminary analysis of the items on the VAC-COVID-19 scale

\begin{tabular}{|c|c|c|c|c|c|}
\hline Variable & $M^{\star}$ & DS $^{\dagger}$ & $A^{\ddagger}$ & $K^{\S}$ & $\mathbf{h}^{\star \star}$ \\
\hline Item 1 & 0.77 & 1.027 & 1.187 & 0.583 & 0.552 \\
\hline Item 2 & 1.213 & 1.217 & 0.607 & -0.746 & 0.665 \\
\hline Item 3 & 0.614 & 0.903 & 1.514 & 1.875 & 0.496 \\
\hline Item 4 & 1.003 & 1.136 & 0.898 & -0.168 & 0.646 \\
\hline Item 5 & 0.575 & 0.884 & 1.747 & 2.945 & 0.564 \\
\hline Item 6 & 0.775 & 0.978 & 1.218 & 0.893 & 0.464 \\
\hline Item 7 & 0.911 & 1.014 & 0.996 & 0.308 & 0.494 \\
\hline Item 8 & 1.801 & 1.282 & -0.015 & -1.204 & 0.379 \\
\hline Item 9 & 2.112 & 1.173 & -0.393 & -0.69 & 0.379 \\
\hline Item 10 & 1.484 & 1.215 & 0.316 & -0.929 & 0.638 \\
\hline Item 11 & 1.608 & 1.259 & 0.238 & -1.073 & 0.329 \\
\hline Item 12 & 1.704 & 1.289 & 0.184 & -1.123 & 0.432 \\
\hline Item 13 & 1.754 & 1.228 & 0.076 & -0.984 & 0.329 \\
\hline Item 14 & 2.789 & 1.082 & -0.826 & 0.114 & 0.692 \\
\hline Item 15 & 2.929 & 1.024 & -1.059 & 0.827 & 0.797 \\
\hline Item 16 & 2.905 & 0.998 & -1.025 & 0.923 & 0.778 \\
\hline Item 17 & 2.4 & 1.136 & -0.311 & -0.682 & 0.402 \\
\hline Item 18 & 1.867 & 1.187 & 0.141 & -0.925 & 0.171 \\
\hline Item 19 & 2.421 & 1.185 & -0.409 & -0.656 & 0.24 \\
\hline
\end{tabular}

* Mean; † Standard Deviation; † Asymmetry coefficient; § Kurtosis coefficient; * Communalities.

Table 2. Exploratory factor analysis of the VAC-COVID-19 scale

\begin{tabular}{|c|c|c|c|}
\hline \# & Items & F1* & $\mathbf{F 2}^{\dagger}$ \\
\hline 1 & I think they are going to insert electronic chips/transistors to control my brain. & 0.665 & \\
\hline 2 & I think SARS-CoV-2 vaccines are part of the plan of a large company that created COVID-19. & 0.814 & \\
\hline 3 & $\begin{array}{l}\text { I think that some SARS-CoV-2 vaccines can come from a former communist republic (like Russia), which } \\
\text { may result in influences on communist thinking. }\end{array}$ & 0.641 & \\
\hline 4 & I think COVID-19 is an invention of the World Health Organization (WHO) or other similar institutions. & 0.793 & \\
\hline 5 & I think COVID-19 does not exist. It is an invention. & 0.691 & \\
\hline 6 & I have already been infected with SARS-Cov-2 and I do not think the vaccine is necessary. & 0.621 & \\
\hline 7 & I think the pandemic is already ending. & 0.705 & \\
\hline 8 & I do not know what and how the vaccines have been made. & 0.654 & \\
\hline 9 & SARS-CoV-2 vaccines can cause side effects or adverse effects. & 0.65 & \\
\hline 10 & I think they want to try the vaccines on us. & 0.798 & \\
\hline 11 & I do not think I belong to a risk group. & 0.619 & \\
\hline 12 & A healthy life is enough to fight disease. & 0.688 & \\
\hline 13 & I do not trust in my health care system (including health care personnel). & 0.608 & \\
\hline 14 & I want to get back to the life I had before the pandemic. & & 0.844 \\
\hline 15 & SARS-CoV-2 vaccines should contribute to improving the health of my family or loved ones. & & 0.945 \\
\hline 16 & I think SARS-CoV-2 vaccines should contribute to improving the health of the community/population. & & 0.897 \\
\hline 17 & I do not want to wear personal protective equipment anymore (masks). & & 0.626 \\
\hline & Variance percentage & $44.27 \%$ & $13.09 \%$ \\
\hline \multicolumn{4}{|c|}{ Inter-factor correlation } \\
\hline & $\mathrm{F} 1^{\star}$ & 1 & \\
\hline & $\mathrm{F}^{\dagger}$ & 0.391 & 1 \\
\hline
\end{tabular}

${ }^{\star} \mathrm{F} 1$ = Factor 1 = Reasons for not receiving vaccination; $† \mathrm{~F} 2$ = Factor 2 = Reasons for receiving vaccination.

items 17 and 18 ("I would be vaccinated only if it is a requirement for work/study" and "if the vaccination is done at home") have communalities lower than 0.30 , so they were not considered in the EFA.

\section{Exploratory Factor Analysis (EFA)}

An EFA was performed and the scale items were saturated in two factors. Results of the KMO coefficient $(\mathrm{KMO}=0.917)$ and the Bartlett's test of sphericity (3343.3; $g \mathrm{l}=136 ; \mathrm{p}<0.001)$ were acceptable and significant. The parallel analysis, unweighted least squares, and oblique promin rotation methods were used. The parallel analysis method suggested that two factors be retained. The rotated solution of the 17 items explains $58.17 \%$ of the total variance. Factor 1 (reasons for not receiving vaccination) explains $44.27 \%$ of the variance, while Factor 2 (reasons for receiving vaccination) $13.09 \%$. All items present saturation greater than 0.60 .

\section{Confirmatory Factor Analysis (CFA)}

Table 3 shows the CFA results based on the internal structure of the VAC-COVID-19 scale. The results of the original model showed that goodness-of-fit was poor. Therefore, items 8 and 9 were eliminated in accordance with the modification indices, and the model was not satisfactory. Items 6 and 7 were eliminated in the second re-specification, showing a variation in the goodness-of-fit indices; however, the model was still not satisfactory. In the third re-specification, items 10 and 11 were eliminated and thus an acceptable factor structure model was found.

The fit indices show that the proposed model is adequate. Also, the correlations between Factors 1 and 2 were significant. In summary, the model of 11 items distributed in two factors is satisfactory (Figure 1). 
Table 3. Goodness-of-fit indices of factorial models of the VAC-COVID-19 scale

\begin{tabular}{|c|c|c|c|c|}
\hline \multirow{2}{*}{ Goodness-of-fit indices } & Original & Model 1 & Model 2 & Model 3 \\
\hline & (17 items) & (15 items) & (13 items) & (11 items) \\
\hline CMIN & 3548.99 & 2300.548 & 1629.663 & 826.321 \\
\hline $\mathrm{df}$ & 118 & 89 & 64 & 43 \\
\hline$p$ & $<0.001$ & $<0.001$ & $<0.001$ & $<0.001$ \\
\hline $\mathrm{CMIN} / \mathrm{df}$ & 30.069 & 25.849 & 25.463 & 19.217 \\
\hline RMR & 0.085 & 0.075 & 0.077 & 0.054 \\
\hline GFI & 0.843 & 0.893 & 0.914 & 0.952 \\
\hline AGFI & 0.797 & 0.856 & 0.878 & 0.927 \\
\hline $\mathrm{CFI}$ & 0.853 & 0.891 & 0.910 & 0.946 \\
\hline TLI & 0.830 & 0.871 & 0.891 & 0.931 \\
\hline RMSEA & 0.099 & 0.091 & 0.091 & 0.078 \\
\hline
\end{tabular}

$\overline{\mathrm{CMIN}}=$ Chi-square goodness-of-fit index; $\mathrm{df}=$ Degrees of freedom; $\mathrm{p}=\mathrm{p}$-value; $\mathrm{CMIN} / \mathrm{df}=$ Chi-square divided by the $\mathrm{df}$ value; $\mathrm{RMR}=\mathrm{Root}$ mean square error; GFI= Goodness-of-fit index; AGFI= Adjusted goodness-of-fit index; CFI= Comparative fit index; TLI= Tucker-Lewis index; RMSEA= Root mean square error of approximation.

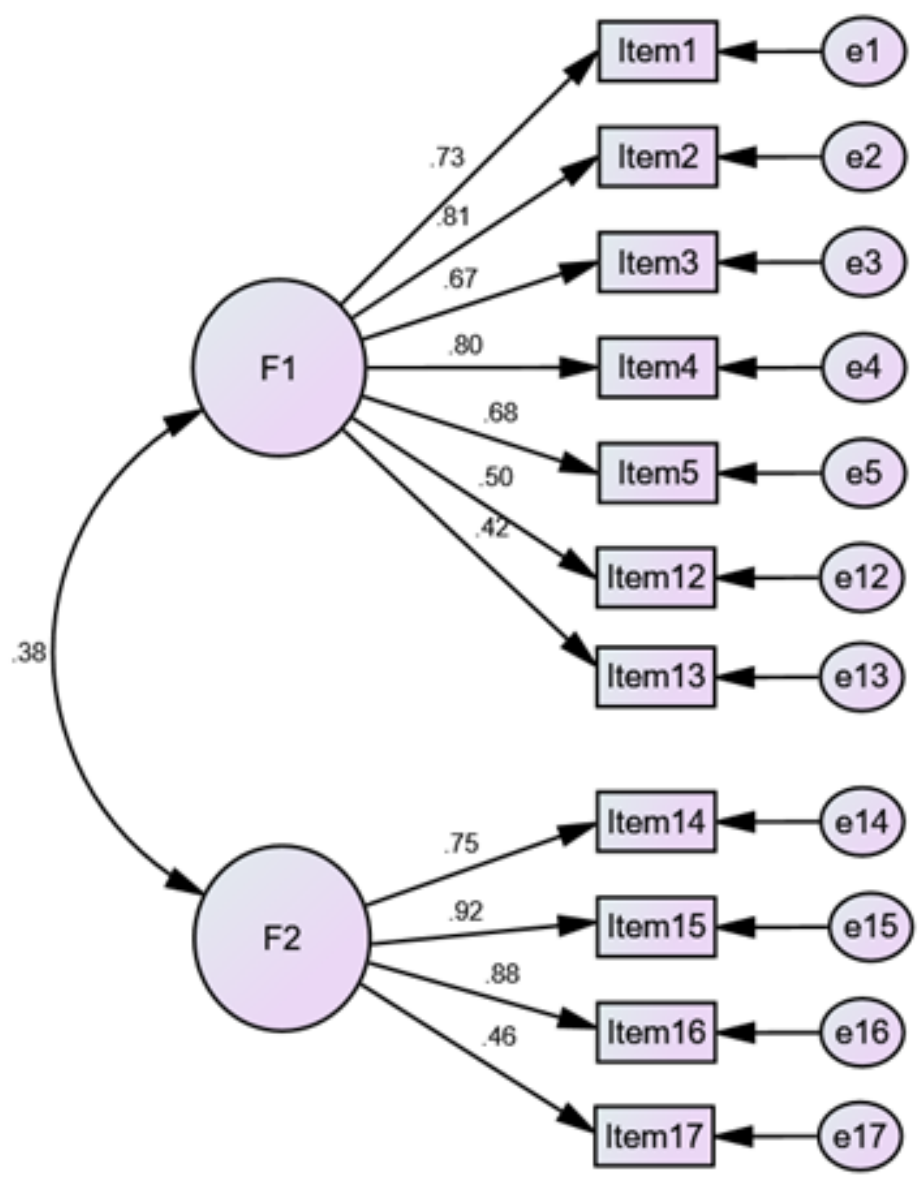

Figure 1. Final model of the VAC-COVID-19 scale

Table 4. Cronbach's a for the VAC-COVID-19 scale and its factors

\begin{tabular}{cccc}
\hline & $\begin{array}{c}\text { Number of } \\
\text { items }\end{array}$ & Cronbach's $\boldsymbol{\alpha}$ & $\begin{array}{c}\text { 95\% Confidence } \\
\text { Interval }\end{array}$ \\
\hline Factor 1 & 7 & 0.834 & $0.82-0.84$ \\
\hline Factor 2 & 4 & 0.837 & $0.82-0.84$ \\
\hline Total Scale & 11 & 0.831 & $0.82-0.84$ \\
\hline
\end{tabular}

\section{Reliability}

The reliability of the scale was estimated with Cronbach's coefficient $\alpha$ [12]. We evidence that the general structure ( $\alpha=$ $0.831 ; 95 \% \mathrm{Cl}=0.82-0.84)$ and all the factors of the scale (Factor 1: $\alpha=0.834 ; 95 \% \mathrm{Cl}=0.82-0.84$ and Factor 2: $\alpha=0.837$; $95 \% \mathrm{Cl}=0.82-0.84$ ) are adequate. Table 4 shows the estimate of reliability for both the scale and its factors, whose reliability coefficients are above higher 0.8 (the acceptable cut-off point is $\geq 0.70$ ), indicating that the VAC-COVID-19 scale is reliable.

\section{DISCUSSION}

The attempts to develop an effective SARS-CoV-2 vaccine have been proceeding rapidly and collaboratively worldwide. However, the existence of a possible level of distrust regarding this vaccine (manufactured by different laboratories) makes it necessary to know how the population perceives it, and thus to understand the doubts and the real confidence in the new vaccines $[13,14]$. Therefore, we validated this scale (VAC- 
COVID-19) in response to the proliferation of many myths and beliefs about the possible adverse effects of immunizations [15]. Our survey is broad in scope and effective and will serve to have a deeper perspective on SARS-CoV-2 vaccination, as well as for further studies, with the ability to contrast the pros and cons based on scientific evidence [16].

The first factor of the study is related to reasons for the population not accepting to be vaccinated against SARS-CoV2. Its respective items allow us to know the reasons for existing myths at the global level, including possible negative influences of powerful groups, the question on the origin of the vaccine (repercussions according to the country that developed it), among other information related to antivaccination movements- mainly transmitted by social networks and the media, which have broadly and quickly disseminated information without considering their accuracy and veracity [17]. Moreover, in the first factor, questions were also asked about the trust that the population has in the health organizations and systems, including the World Health Organization, since in many countries there is a degree of mistrust on their own health systems and vaccination programs [18]. Therefore, using the knowledge gained from answering these questions, it becomes possible to help guide the health authorities to develop specific strategies to increase the trust of the population in SARS-CoV-2 vaccines. A good example of this has occurred in Chile, where there is the highest rate of trust in vaccination with respect to the influenza vaccination program in Latin America; due to its population have higher knowledge and perception levels about influenza risks [19].

The second factor consists of four items about the most important reasons as to why the population should receive SARS-CoV-2 vaccination. The answers to these questions are very important to know, as they also should help authorities in the development of more effective public health strategies against the COVID-19 pandemic. In this context, a major current concern is the return to activities of daily living (as before the pandemic), since the confinement can lead to several negative health consequences, such as stress, anxiety, and fear [20-22]. It is worth remembering that many people have been away from their families and other loved ones. Furthermore, many people are no longer properly using personal protective equipment; despite the fact that the mask protects, its use has caused some dermatological problems, including acne, contact dermatitis, ulcers, and erosions [20].

It should also be noted that the present survey mainly aims to measure the willingness of general population to receive SARS-CoV-2 vaccination, with acceptable Cronbach's alpha values $(a=0.831)$. In 2016, Shapiro et al developed a scale that measures vaccine conspiracy beliefs regarding human papillomavirus (HPV) vaccine with the participation of 1427 Canadian parents. This 7-items scale obtained a reliable Cronbach's alpha $(a=0.937)$. However, such scale had a higher inter-factor correlation (0.82) [23] than the scale developed by us (0.391). On the other hand, in 2017, Forster et al validated a scale that assesses HPV vaccination knowledge, involvement in the vaccine decision-making, self-efficacy with regard to getting the vaccine, and fear and anxiety about vaccination. In this case, the developed scale has three sections and each of them was validated obtaining Cronbach's alpha values ( $a=$ $0.60,0.79,0.79$ ) lower [24] than ours.

One of the limitations of our study was that it cannot be extrapolated to the entire Peruvian population, since the sample selection was not randomized. Therefore, although the present research has been conducted in all the regions of Peru, the fact of we used a non-random type of sampling meant that the study cannot be extrapolated, for example, to the rural population. Another limitation is the absence of concurrent validity assessment. We strongly recommend that in future studies this assessment is carried out. Moreover, we suggest further validations on this issue.

In conclusion, the VAC-COVID-19 scale is a valid and reliable instrument of public health to measure the perception of SARSCoV-2 vaccines acceptance. This scale can be very useful to determine the reasons why different populations adhere or not to the vaccination, in order to help propose adequate and effective strategies to advance vaccination coverage rates.

Author contributions: All authors have sufficiently contributed to the study, and agreed with the results and conclusions.

Funding: This study was supported by the Universidad Norbert Wiener in Lima, Peru.

Declaration of interest: CRM and OR-L work in the institution which financed the research.

\section{REFERENCES}

1. Johns Hopkins Coronavirus Resource Center. World Map. Baltimore. Available at: https://coronavirus.jhu.edu/ map.html (Accessed: 21 January 2021).

2. Dong L, Bouey J. Public mental health crisis during COVID19 pandemic, China. Emerg Infect Dis. 2020;26(7):1616-8. https://doi.org/10.3201/eid2607.202407 PMid:32202993 PMCid:PMC7323564

3. Redacción El Comercio. IPE: ¿Cuál es la cobertura de vacunación en el país y cómo se ha visto impactada por el COVID-19?. Lima: El Comercio Perú; 2020. Available at: https://elcomercio.pe/economia/peru/ipe-cual-es-la-

cobertura-de-vacunacion-en-el-pais-y-como-se-ha-vistoimpactada-por-el-covid-19-noticia/ (Accessed: 21 January 2021).

4. Opel DJ, Salmon DA, Marcuse EK. Building trust to achieve confidence in COVID-19 vaccines. JAMA Netw Open. 2020;3(10):e2025672. https://doi.org/10.1001/jamanet workopen.2020.25672 PMid:33079194

5. Kreps S, Prasad S, Brownstein JS, Hswen Y, Garibaldi BT, Zhang B, et al. Factors Associated with US adults' likelihood of accepting COVID-19 vaccination. JAMA Netw Open. 2020;3(10):e2025594. https://doi.org/10.1001/jamanet workopen.2020.25594 PMid:33079199 PMCid:PMC7576409

6. Neumann-Böhme S, Varghese NE, Sabat I, Barros PP, Brouwer W, van Exel J, et al. Once we have it, will we use it? A European survey on willingness to be vaccinated against COVID-19. Eur J Health Econ. 2020;21(7):977-82. https://doi.org/10.1007/s10198-020-01208-6 PMid:32591957 PMCid:PMC7317261

7. Wang J, Jing R, Lai $X$, Zhang $H$, Lyu $Y$, Knoll MD, et al. Acceptance of COVID-19 vaccination during the COVID-19 pandemic in China. Vaccines (Basel). 2020;8(3):482. https://doi.org/10.3390/vaccines8030482 PMid:32867224 PMCid:PMC7565574

8. Malik AA, McFadden SM, Elharake J, Omer SB. Determinants of COVID-19 vaccine acceptance in the US. EClinicalMedicine. 2020;26:100495. https://doi.org/10.1016 /j.eclinm.2020.100495 PMid:32838242 PMCid:PMC7423333

9. Tabachnick BG, Fidell LS, Ullman JB. Using Multivariate Statistics. 7th ed. New York, NY: Pearson; 2019. 
10. Lorenzo-Seva U, Ferrando PJ. FACTOR: A computer program to fit the exploratory factor analysis model. Behav Res Methods. 2006;38(1):88-91. https://doi.org/10.3758/ BF03192753 PMid:16817517

11. Hu L, Bentler PM. Cutoff criteria for fit indexes in covariance structure analysis: conventional criteria versus new alternatives. Struct Equ Modeling. 1999;6(1):1-55. https://doi.org/10.1080/10705519909540118

12. Domínguez-Lara SA, Merino-Soto C. ¿Por qué es importante reportar los intervalos de confianza del coeficiente alfa de Cronbach? Rev. Latinoam. Cienc. Soc. Niñez Juv. 2015;13(2):1326-8.

13. Palamenghi L, Barello S, Boccia S, Graffigna G. Mistrust in biomedical research and vaccine hesitancy: the forefront challenge in the battle against COVID-19 in Italy. Eur J Epidemiol. 2020;35(8):785-8. https://doi.org/10.1007/ s10654-020-00675-8 PMid:32808095 PMCid:PMC7431109

14. Salali GD, Uysal MS. COVID-19 vaccine hesitancy is associated with beliefs on the origin of the novel coronavirus in the UK and Turkey. Psychol Med. 2020;1-3. https://doi.org/10.1017/S0033291720004067 PMid:33070804 PMCid:PMC7609204

15. Domínguez A, Astray J, Castilla J, Godoy P, Tuells J, Barrabeig I. Falsas creencias sobre las vacunas. Aten Primaria. 2019;51(1):40-6. https://doi.org/10.1016/ j.aprim.2018.05.004 PMid:30262223 PMCid:PMC6836946

16. Muñoz-Cruzado y Barba M. Reflexión ante la vacuna de la COVID-19. Rev. Esp. Comun. Salud. 2020;11(2):175-7. https://doi.org/10.20318/recs.2020/5814

17. Cornwall W. Officials gird for a war on vaccine misinformation. Science. 2020;369(6499):14-5. https://doi. org/10.1126/science.369.6499.14 PMid:32631873

18. Cobos Muñoz D, Monzón Llamas L, Bosch-Capblanch X. Exposing concerns about vaccination in low- and middleincome countries: a systematic review. Int J Public Health. 2015;60(7):767-80. https://doi.org/10.1007/s00038-0150715-6 PMid:26298444
19. González-Block MÁ, Gutiérrez-Calderón E, PelcastreVillafuerte BE, Arroyo-Laguna J, Comes Y, Crocco P, et al. Influenza vaccination hesitancy in five countries of South America. Confidence, complacency and convenience as determinants of immunization rates. PLoS One. 2020;15(12):e0243833. https://doi.org/10.1371/journal. pone.0243833 PMid:33306744 PMCid:PMC7732123

20. Musinguzi G, Asamoah BO. The Science of social distancing and total lock down: does it work? whom does it benefit?. Electron J Gen Med. 2020;17(6):em230. https://doi.org/ 10.29333/ejgm/7895

21. Mejia CR, Rodríguez-Alarcón JF, Carbajal M, SifuentesRosales J, Campos-Urbina AM, Charri JC, et al. Validación de una escala breve para la medición del nivel de conocimientos básicos acerca del Coronavirus, Perú (KNOW-P-COVID-19). Kasmera. 2020;48(1): e48106042020.

22. Mejia CR, Rodríguez-Alarcón JF, Carbajal M, Pérez-Espinoza P, Porras-Carhuamaca LA, Sifuentes-Rosales J, et al. Fatalismo ante la posibilidad de contagio por el coronavirus: generación y validación de un instrumento (FCOVID-19). Kasmera. 2020;48(1):e48118032020.

23. Shapiro GK, Holding A, Perez S, Amsel R, Rosberger Z. Validation of the vaccine conspiracy beliefs scale. Papillomavirus Res. 2016;2:167-72. https://doi.org/10.1016 /j.pvr.2016.09.001 PMid:29074176 PMCid:PMC5886898

24. Forster AS, McBride KA, Davies C, Stoney T, Marshall H, McGeechan K, et al. Development and validation of measures to evaluate adolescents' knowledge about human papillomavirus (HPV), involvement in HPV vaccine decision-making, self-efficacy to receive the vaccine and fear and anxiety. Public Health. 2017;147:77-83. https://doi.org/10.1016/j.puhe.2017.02.006 PMid:28404501 PMCid:PMC5476903 


\section{APPENDIX}

Items of the final survey (from Table 2) written in English (Table A1), Spanish (Table A2), and Portuguese languages (Table A3).

Table A1. Items in English

I shouldn't get SARS-CoV-2 vaccines because...

1 . I think they are going to insert electronic chips/transistors to control my brain.

2. I think SARS-CoV-2 vaccines are part of the plan of a large company that created COVID-19.

3. I think that some SARS-CoV-2 vaccines can come from a former communist republic (like Russia), which may result in influences on communist thinking.

4. I think COVID-19 is an invention of the World Health Organization (WHO) or other similar institutions.

5. I think COVID-19 does not exist. It is an invention.

12. A healthy life is enough to fight disease.

13. I do not trust in my health care system (including health care personnel).

I should get SARS-CoV-2 vaccines because...

14. I want to get back to the life I had before the pandemic.

15. SARS-CoV-2 vaccines should contribute to improving the health of my family or loved ones.

16. I think SARS-CoV-2 vaccines should contribute to improving the health of the community/population.

17. I do not want to wear personal protective equipment anymore (masks).

Table A2. Items in Spanish

No debería ponerme las vacunas contra el SARS-CoV-2 porque...

1. Pienso que me van a insertar chips/transistores electrónicos para controlar mi cerebro.

2. Pienso que las vacunas contra el SARS-CoV-2 son parte del plan de una gran empresa que creó el COVID-19.

3. Pienso que algunas vacunas contra el SARS-Cov-2 pueden provenir de una antigua república comunista (como Rusia), resultando en influencias en el pensamiento comunista.

4. Pienso que el COVID-19 es un invento de la Organización Mundial de la Salud (OMS) u otras instituciones similares.

5. Pienso que el COVID-19 no existe, es un invento.

12. Una vida saludable es suficiente para combatir las enfermedades.

13. No confío en mi sistema de salud (incluído el personal de salud).

Debería ponerme las vacunas contra el SARS-CoV-2 porque ...

14. Quiero regresar a mi vida de antes de la pandemia.

15. Las vacunas contra el SARS-CoV-2 deben contribuir a mejorar la salud de mi familia o seres queridos.

16. Las vacunas contra el SARS-CoV-2 deben contribuir a mejorar la salud de la comunidad/población.

17. No quiero seguir usando equipos de protección personal (mascarillas)

Table A3. Items in Portuguese

Eu não deveria tomar as vacinas contra o SARS-CoV-2 porque...

1. Eu penso que elas vão inserir chips/transistores eletrônicos para controlar meu cérebro.

2. Eu penso que as vacinas contra o SARS-CoV-2 fazem parte do plano de uma grande empresa que criou a COVID-19.

3. Eu penso que algumas das vacinas contra o SARS-CoV-2 podem vir de uma ex-república comunista (como a Rússia), o que deve resultar em influências no pensamento comunista.

4. Eu penso que a COVID-19 é uma invenção da Organização Mundial da Saúde (OMS) ou de outras instituições similares.

5. Eu penso que a COVID-19 não existe, é uma invenção.

12. Uma vida saudável é o suficiente para combater as doenças.

13. Não confio no meu sistema de saúde (incluindo os profissionais de saúde).

Eu deveria tomar as vacinas contra o SARS-CoV-2 porque...

14. Quero voltar para minha rotina anterior à pandemia.

15. As vacinas contra o SARS-CoV-2 devem contribuir para melhorar a saúde da minha família ou entes queridos.

16. As vacinas contra o SARS-CoV-2 devem contribuir para melhorar a saúde da comunidade/população.

17. Não quero continuar usando equipamentos de proteção individual (máscaras). 